\title{
Nonalcoholic steatohepatitis in posttransplantation liver: Review article
}

\author{
Antônio Ricardo Cardia Ferraz de Andrade ${ }^{1,2 *}$ @, Helma P. Cotrim $^{1}$, Paulo L. Bittencourt ${ }^{2}$, Carolina G. Almeida ${ }^{1}$, \\ Ney Christian Amaral Boa Sorte ${ }^{1}$
}

${ }^{2}$ Medicine and Health Graduate Program, Faculdade de Medicina da Bahia da Universidade Federal da Bahia, Salvador, BA, Brazil

${ }^{2}$ Hospital Português, Salvador, BA, Brazil

Study conducted by the Medicine and Health Graduate Program, Faculdade de Medicina da Bahia da Universidade Federal da Bahia, Salvador, BA, Brazil

Article received: $3 / 19 / 2017$ Accepted for publication: 6/26/2017

*Correspondence: Address: Rua Padre Camilo Torrend, 145/402

Salvador, BA - Brasil Postal code: 40210-650 arcfa@ufba.br

http://dx.doi.org/10.1590/1806-9282.64.02.187

\section{SUMMARY}

Introduction: Nonalcoholic steatohepatitis (NASH) associated or not with cirrhosis is the third leading indication for liver transplantation (LT) around the world. After transplants, NASH has a high prevalence and occurs as both recurrent and de novo manifestations. De novo NASH can also occur in allografts of patients transplanted for non-NASH liver disease.

Objective: To evaluate recurrent or de novo NASH in post-LT patients.

Method: A literature review was performed using search engines of indexed scientific material, including Medline (by PubMed), Scielo and Lilacs, to identify articles published in Portuguese and English until August 2016. Eligible studies included: place and year of publication, prevalence, clinical characteristics, risk factors and survival.

Results: A total of 110 articles were identified and 63 were selected. Most of the studies evaluated recurrence and survival after LT. Survival reached $90-100 \%$ in 1 year and $52-100 \%$ in 5 years. Recurrence of NAFLD (steatosis) was described in $15-100 \%$ and NASH, in 4-71\%. NAFLD and de novo NASH were observed in 18-67\% and $3-17 \%$, respectively. Metabolic syndrome, diabetes mellitus, dyslipidemia and hypertension were seen in $45-58 \%, 18-59 \%, 25-66 \%$ and $52-82 \%$, respectively.

Conclusion: After liver transplants, patients present a high prevalence of recurrent and de novo NASH. They also show a high frequence of metabolic disorders. Nevertheless, these alterations seem not to influence patient survival.

Keywords: Nonalcoholic Fatty Liver Disease. Liver Transplantation. Fatty Liver. Metabolic Syndrome. Diabetes Mellitus.

\section{INTRODUCTION}

Nonalcoholic fatty liver disease (NAFLD) affects about a third of the Western population, being the largest cause of elevation of aminotransferases in the world. ${ }^{1}$ It is a broad spectrum pathological condition that includes steatosis, steatohepatitis (NASH), fibrosis and eventually cirrhosis (Figure 1) and hepatocellular carcinoma (HCC)., ${ }^{2,3}$

Steatosis may have a slow and asymptomatic course, but in $20 \%$ to $30 \%$ of cases it progresses to steatohepatitis, the stage of disease with the greatest potential for progression to cirrhosis and HCC (Figure 1).

Factors associated with the development of NASH include obesity, diabetes mellitus (DM), dyslipidemia and insulin resistance, which makes this disorder increas- ingly recognized as the hepatic component of metabolic syndrome (MetS). ${ }^{4}$ Compared to the general population, NASH patients have increased cardiovascular risk and mortality. ${ }^{5}$ The significant increase in morbidity and mortality due to the obesity epidemic caused NAFLD, especially NASH combined with cirrhosis, to become the $3^{\text {rd }}$ largest cause of liver transplantation, with the estimate that it will be the leading cause in 20 years. ${ }^{6,7}$

After transplantation, some studies have observed up to $100 \%$ recurrence of NAFLD after 5 years. ${ }^{8-10}$ The appearance of NAFLD in transplanted patients due to causes other than NASH, i.e. de novo NAFLD, was first described by Poordad et al. ${ }^{11}$ in patients undergoing transplantation on account of hepatitis C. Due to better results after he- 


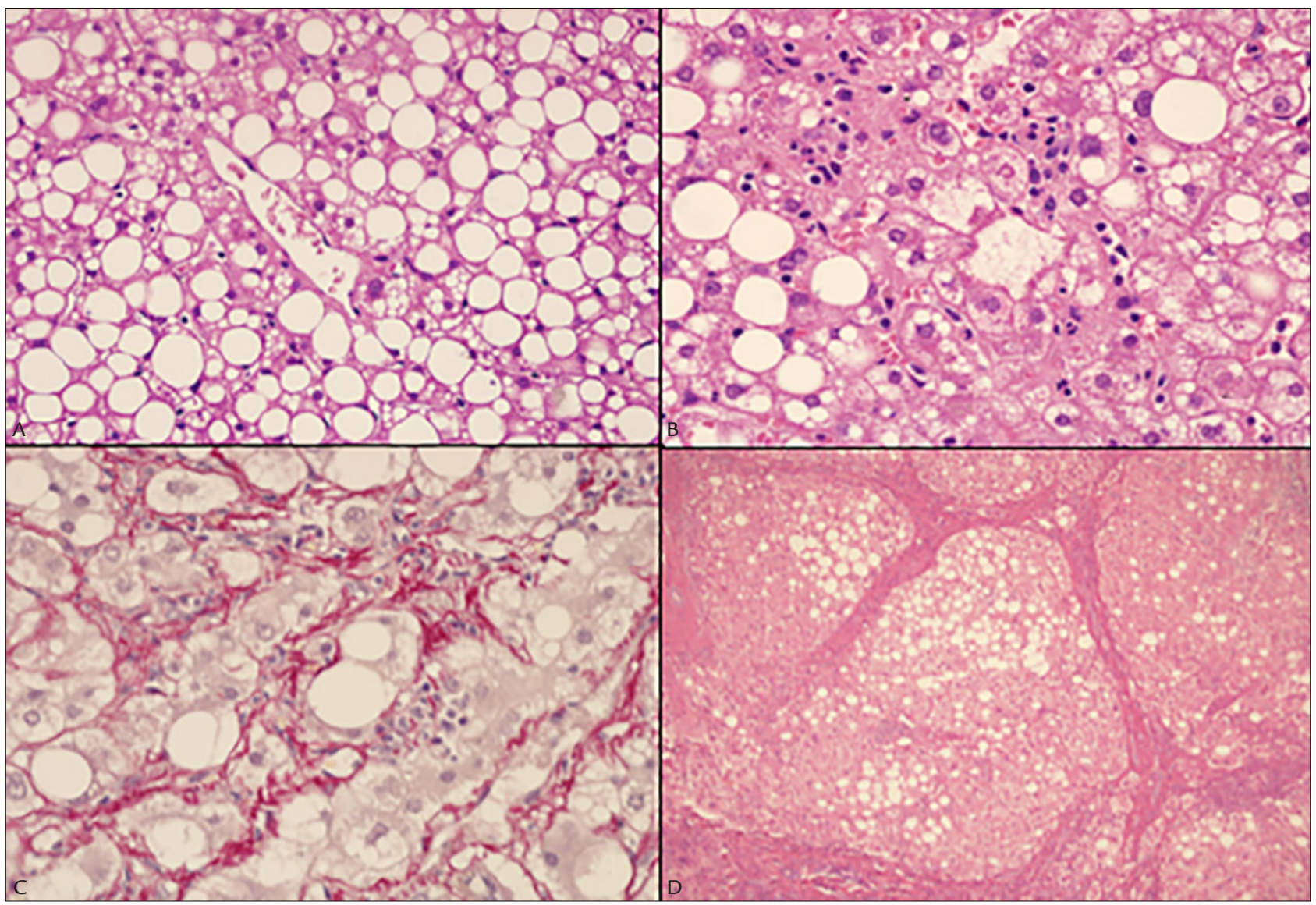

FIGURE 1 A. Steatosis: micro and macrovacuolar. B. Nonalcoholic steatohepatitis (NASH): steatosis, lobular inflammation and hepatocellular ballooning. C. Perisinusoidal fibrosis. D. Cirrhosis.

Courtesy of Professor Luiz Antônio Rodrigues Freitas.

patic transplantation, increased survival in the first year posttransplantation, and better control of chronic rejection, ${ }^{12}$ an increased incidence of later changes such as de novo NAFLD and cardiovascular complications was noted..$^{13}$

This review of the literature aimed to evaluate the relevance of recurrence or de novo NASH in liver transplant patients.

\section{Method}

Scientific articles indexed through PubMed, including Medline, SciELO and Lilacs, published in English and Portuguese, were used as search methods.

Prevalence, incidence, clinical characteristics, risk factors and survival in liver transplant patients were evaluated. The terms used in English were "NAFLD" or "NASH" or "steatosis" or "fatty liver" and "recurrency" and/or "liver transplantation." In Portuguese, we used as search terms "DHGNA" or "esteato-hepatite" or "esteatose" and/ or "de novo", and/or "recorrência" and/or "transplante hepático." According to the study design, cross-sectional, longitudinal or descriptive investigations were included, with patients over 18 years of age, showing site and year of publication, prevalence and/or clinical characteristics of the patients, being published until August 2016.

\section{Results}

The initial search yielded 1,285 studies. We removed 423 duplicate articles and 752 after reading titles and abstracts, since they did not address the issue with relevance. Following the proposed theme, 110 articles were identified and 63 were selected. We excluded 47 articles because they were review studies or case reports. The selected studies were conducted in Europe, Asia and North America, and five were Brazilian. ${ }^{1417}$ Samples ranged from 7 to 10,204 patients and, due to the heterogeneity of the subject, the studies were grouped according to the following topics.

\section{Survival}

Sixteen (16) articles discussed the survival of patients transplanted by NASH (Table 1) and some of these articles 
included in their statistics patients who were transplanted due to cryptogenic cirrhosis. No difference was observed in the mean survival of patients undergoing transplantation because of NASH compared to the survival of patients transplanted due to other etiologies. Only one study by Afzali et al. ${ }^{18}$ showed survival at 5 years in NASH transplanted patients as higher than patients with alcoholic disease, hepatitis $\mathrm{C}(\mathrm{HCV})$ and hepatocellular carcinoma (HCC). Some studies failed to show differences in survival between patients transplanted due to NASH or other causes. ${ }^{21,22,26,31}$ Malik et al. ${ }^{31}$ found no difference in survival between patients who underwent transplantation due to NASH who relapsed compared to those who did not relapse.

Mortality and cardiovascular events are more common in patients transplanted due to NASH in the first few years after transplantation. We found 11 studies regarding cardiovascular mortality with a number of patients ranging from 21 to 5,653, totaling 7,662 patients evaluated with a follow-up period of 3 to 10 months. Cardiovascular mortality ranged from $7 \%$ to $26 \%{ }^{18,22-24,26,27,31,33-36}$ Compared to transplanted patients due to other etiologies, the incidence is $15 \%$ higher in the first year ${ }^{37}$ but does not increase the overall mortality after one year or in the long term compared to the other etiologies..$^{36,38}$

\section{TABLE 1 Survival of NASH patients undergoing}

liver transplantation.

\begin{tabular}{|c|c|c|c|c|}
\hline Reference & $\begin{array}{l}\text { Patients } \\
\mathrm{N}\end{array}$ & $\begin{array}{l}\text { Survival } \\
1 \text { year } \\
(\%)\end{array}$ & $\begin{array}{l}\text { Survival } \\
3 \text { years } \\
(\%)\end{array}$ & $\begin{array}{l}\text { Survival } \\
5 \text { years } \\
(\%)\end{array}$ \\
\hline Charlton et al. ${ }^{6}$ & 1,840 & 84 & 78 & - \\
\hline Afzali et al. ${ }^{18}$ & $1,810+3,843^{c c}$ & $=87$ & 81 & 75 \\
\hline El Atrache et al. ${ }^{\# 19}$ & 83 & - & - & 52 \\
\hline Dureja et al. ${ }^{20}$ & 11 & 78 & - & - \\
\hline Agopian et al. ${ }^{21}$ & 144 & 84 & 75 & 70 \\
\hline Kennedy et al. ${ }^{22}$ & 129 & 90 & 88 & 85 \\
\hline Barritt et al. ${ }^{23}$ & 21 & 76 & 76 & - \\
\hline Yalamanchili et al. ${ }^{24}$ & $18+239^{c c}$ & 86 & - & 71 \\
\hline Heuer et al. ${ }^{25}$ & 40 & 75 & - & - \\
\hline Bhagat et al. ${ }^{26}$ & 71 & 82 & 79 & 75 \\
\hline VanWagner et al. ${ }^{27}$ & 30 & 81 & 73 & 60 \\
\hline Houlihan et al. ${ }^{28}$ & 48 & 88 & 82 & \\
\hline Tanaka et al. ${ }^{29}$ & 7 & 100 & 100 & 100 \\
\hline Singal et al. ${ }^{30}$ & 1,368 & 86 & 82 & 80 \\
\hline Malik et al. ${ }^{31}$ & 98 & 79 & 74 & 72 \\
\hline Hejlova et al. ${ }^{* 32}$ & 309 & - & 100 & 94 \\
\hline
\end{tabular}

\#Survival in a patient with metabolic syndrome.

* Evaluated the survival of patients with de novo NAFLD. In this study, the 10-year survival rate was $81 \%$.

${ }^{c c}$ Cryptogenic cirrhosis was evaluated in conjunction with patients transplanted due to $\mathrm{NASH}$ in these studies.

\section{Recurrence of NASH and de novo NASH}

We selected 11 articles that addressed the recurrence of NASH, as shown in Table 2.

The studies of Contos et al., ${ }^{9}$ Ong et al., ${ }^{10}$ El Atrache et al., ${ }^{19}$ and Dureja et al. ${ }^{20}$ found advanced fibrosis, greater than grade 3 , in about $4 \%$ of the samples. Contos et al. ${ }^{9}$ associate the increased recurrence of NAFLD with the use of corticosteroids. Charlton et al., ${ }^{39}$ in an earlier study conducted in 2001 , showed $12.5 \%$ of cirrhotic patients, a percentage higher than the one found in more recent studies. It is possible that the higher frequency of recurrence in the older series, as well as the greater severity of the cases in that period, is related to the type of immunosuppression used at the time, more strongly based on corticosteroids.

We found eight articles reporting the presence of de novo NASH.

The onset of de novo NASH occurs as of the sixth month posttransplant, only after nutritional recovery from the immediate posttransplant.

As observed in Table 2, the incidence is high, and increases according to the follow-up time. ${ }^{30,42}$ Hejlova et al. ${ }^{32}$ found an increase from $30 \%$ after 1 year to $47 \%$ after 10 years. The series studied showed a low incidence of severe forms of the disease, at most 3\%, except for Hejlova et al. ${ }^{32}$ who showed $17 \%$ of advanced fibrosis, probably associated to the longer follow-up of the patients. Even so, there was no difference in the survival of patients with F3/F4 fibrosis compared to the others. There is no report of retransplantation or graft dysfunction.

The studies associate as factors related to de novo NASH the use of tacrolimus, ${ }^{12} \mathrm{DM},{ }^{12}$ dyslipidemia, ${ }^{12,30}$ high blood pressure (HBP), ${ }^{12}$ alcoholic cirrhosis, ${ }^{12}$ donor with a fatty liver ${ }^{43}$ and weight gain after transplantation..$^{12,30,37}$

\section{Risk factors}

Risk factors for NASH were found in 29 studies. Of these, eight reported on MetS. The authors observed that patients transplanted due to NASH have an incidence of MetS similar to those transplanted for other reasons, around $50 \%$ (Table 3). In the series evaluated by Laish et al. ${ }^{35}$ and El Atrache et al., ${ }^{19}$ the population evaluated consisted exclusively of patients transplanted due to NASH. In the investigation by Seo et al. ${ }^{40}$ the population consisted of patients with de novo NASH. Despite the known relation between insulin resistance and metabolic syndrome, there are few articles evaluating posttransplant insulin resistance. The only studies, by Bianchi et al..$^{45}$, Anastácio et al. ${ }^{14}$ and Veldt et al. ${ }^{59}$ showed a value of the HOMA index very close to that considered normal in the several populations and in the index study by Marchesini et al. ${ }^{60}$ that considered 3 
TABLE 2 Recurrence of NASH and de novo NASH in patients undergoing liver transplantation.

\begin{tabular}{|c|c|c|c|c|c|c|}
\hline \multirow[t]{2}{*}{ Reference } & \multirow[t]{2}{*}{ Patients $\mathbf{N}$} & \multirow[t]{2}{*}{ Follow-up (months) } & \multicolumn{2}{|l|}{ Recurrence } & \multicolumn{2}{|l|}{ De novo } \\
\hline & & & NAFLD (\%) & NASH (\%) & NAFLD (\%) & NASH (\%) \\
\hline Yalamanchili et al. ${ }^{24}$ & 18 & 60 & 45 & 4 & & \\
\hline Tanaka et al. ${ }^{29}$ & 7 & 120 & 14 & - & & \\
\hline Bhagat et al. ${ }^{26}$ & 71 & 60 & - & 33 & & \\
\hline Contos et al. ${ }^{9}$ & 27 & $>12$ & 52 & 11 & & \\
\hline Charlton et al. ${ }^{39}$ & 15 & $>12$ & 60 & 33 & & \\
\hline Dureja et al. ${ }^{20}$ & 88 & $>12$ & 39 & 28 & & \\
\hline El Atrache et al. ${ }^{19}$ & 83 & 45 & - & 24 & & \\
\hline Ong et al. ${ }^{10}$ & 51 & $>24$ & 25.5 & 16 & & \\
\hline Vallin et al. ${ }^{8}$ & 11 & $>60$ & 100 & 71.4 & & \\
\hline Malik et al. ${ }^{31}$ & 98 & 60 & - & 25 & & \\
\hline Agopian et al. ${ }^{21}$ & 144 & 60 & 15 & 8 & & \\
\hline Seo et al. ${ }^{40}$ & 68 & 28 & & & 18 & 9 \\
\hline Sprinzl et al. ${ }^{41}$ & 129 & 24 & & & 34 & 5.4 \\
\hline Dumortier et al. ${ }^{12}$ & 421 & $>6$ & & & 31 & 5.3 \\
\hline Kim et al. ${ }^{43}$ & 156 & $>12$ & & & 27 & 6.7 \\
\hline Hejlova et al. ${ }^{32}$ & 546 & $>120$ & & & 56.7 & 10 \\
\hline Lim et al. ${ }^{37}$ & 30 & 44 & & & 40 & 13 \\
\hline Vallin et al. ${ }^{8}$ & 80 & $>60$ & & & 67 & 17.2 \\
\hline Finkenstedt et al. ${ }^{42}$ & 237 & $>60$ & & & 32.6 & \\
\hline
\end{tabular}

as cutoff point. Bianchi et al. ${ }^{45}$ found a value of 3.1 in patients with MetS. Anastácio et al. ${ }^{14}$ found 2.4 in a Brazilian population and Veldt et al. ${ }^{59} 2.2$ and 1.2 in diabetic and non-diabetic patients, respectively.

\section{Posttransplant diabetes mellitus}

Diabetes is often found in patients after liver transplantation. The population of pretransplant diabetics varies according to the etiology of the transplantation, most often NASH, and the characteristics of this population (obesity, age and ethnicity - more frequent among Westerners). Posttransplant diabetes (NODAT, New Onset Diabetes After Transplantation) is related to obesity, family history, glucose intolerance prior to transplantation, and hepatitis $\mathrm{C}$ as the etiology of transplantation, but it is also related to immunosuppressants. There are a number of studies arguing that the pathophysiology of NODAT is immunosuppressive toxicity in pancreatic B cells. ${ }^{33,61,62}$

As shown in Table 3, which includes 18 studies on diabetes, the longer the population follow-up, the higher the prevalence. Only one study associates NODAT with a lower frequency of sarcopenia and lower mortality in the first year posttransplantation. An explanation for this fact would probably be related to the better nutritional recovery seen in these patients. ${ }^{57}$ There is no association of NODAT with graft dysfunction and decreased survival. ${ }^{63}$ Even though studies evaluating patients with posttransplant NAFLD ${ }^{8,19,40,45}$ yield prevalence rates for diabetes similar to those of the general population, there is an investigation by Stepanova et al. ${ }^{64}$ including over 15,000 transplanted patients, some 3,000 of which transplanted due to NASH, which eventually concluded that the latter have a higher risk of developing DM.

Dyslipidemia, hypertension and obesity in liver transplant patients

It is known that transplanted patients have a higher incidence of dyslipidemia and hypertension. Currently, the basis of immunosuppressive treatment is performed with calcineurin inhibitors. Some studies compared patients who used different immunosuppressants. Bianchi et al., ${ }^{45}$ as well as other authors, ${ }^{55,58}$ compared patients who used cyclosporine and tacrolimus, with an incidence of MetS of 52 vs. 60 , HBP of 59 vs. 41 , dyslipidemia of 57 vs. 38 , and DM of 34 vs. 44, respectively. Although both favor metabolic disorders, cyclosporin is more associated with hypertension and dyslipidemia, whereas tacrollimus is associated with increased DM frequency (Table 3). The 
TABLE 3 Frequency of metabolic disorders in patients undergoing liver transplantation.

\begin{tabular}{|c|c|c|c|c|c|c|c|}
\hline Reference & Patients N & Follow-up (months) & MetS (\%) & DM (\%) & NODAT (\%) & Dyslipid (\%) & HBP (\%) \\
\hline Sprinzl et al. ${ }^{41}$ & 44 & 24 & 48 & & & & 52 \\
\hline Seo et al. ${ }^{40}$ & 68 & 28 & & 38 & & 25 & 69 \\
\hline El Atrache et al. ${ }^{19}$ & 83 & 45 & 53 & 76 & & & 71 \\
\hline Hanouneh et al. ${ }^{44}$ & 148 & 60 & 53 & 59 & & & 60 \\
\hline Bianchi et al. ${ }^{45}$ & 296 & 38 & 45 & 38 & 29.4 & 50 & 52.7 \\
\hline Laryea et al. ${ }^{46}$ & 118 & $>60$ & 58 & & & 48 & 62 \\
\hline Laish et al. ${ }^{35}$ & 252 & $>60$ & 52 & & & & \\
\hline Anastácio et al. ${ }^{47}$ & 148 & $>60$ & 50 & & & & 60 \\
\hline Yalamanchili et al. ${ }^{24}$ & 257 & 60 & & 36.8 & & & 52 \\
\hline Lv et al. ${ }^{48}$ & 438 & 60 & & 18 & & & \\
\hline Dumortier et al. ${ }^{12}$ & 421 & $>6$ & & 23.5 & & 12 & 51.8 \\
\hline Marroni et al. ${ }^{16}$ & 75 & $>3$ & & 38 & & & \\
\hline Kennedy et al. ${ }^{22}$ & 129 & $>60$ & & 59 & & & \\
\hline Ong et al. ${ }^{10}$ & 13 & $>60$ & & 53 & & & \\
\hline Agopian et al. ${ }^{21}$ & 144 & 60 & & 57 & & & 50 \\
\hline Vallin et al. ${ }^{8}$ & 80 & $>60$ & & 37.8 & & & 52 \\
\hline Parolin et al. ${ }^{17}$ & 82 & 20 & & & 18.9 & & \\
\hline Mirabella et al. ${ }^{49}$ & 830 & 10 & & & 10.8 & & \\
\hline Ling et al. ${ }^{50}$ & 10,204 & 30 & & & 24.3 & & \\
\hline Carey et al..$^{51}$ & 225 & $>12$ & & & 17.3 & & \\
\hline Saliba et al. ${ }^{52}$ & 211 & 24 & & & 22.7 & & \\
\hline Moon et al. ${ }^{53}$ & 778 & 57 & & & 36.5 & & \\
\hline Gisbert et al. ${ }^{54}$ & 85 & $>12$ & & & & 66 & \\
\hline Trotter et al. ${ }^{\# 55}$ & 57 & $>6$ & & & & 30 & \\
\hline Dehghani et al. ${ }^{* 56}$ & 170 & $>12$ & & & & 70 & \\
\hline Marroni et al. ${ }^{15}$ & 75 & $>3$ & & & & & $14^{* *}$ \\
\hline Darstein et al. ${ }^{57}$ & 255 & $>60$ & & & & & 55 \\
\hline Hejlova et al. ${ }^{32}$ & 309 & $>120$ & & & & & 67 \\
\hline Canzanello et al. ${ }^{¥ 58}$ & 158 & $>24$ & & & & & 82 \\
\hline
\end{tabular}

"The authors found $30 \%$ in patients who used cyclosporine and $6 \%$ with tacrolimus.

*The authors found $70 \%$ of hypertriglyceridemia and $15 \%$ of hypercholesterolemia.

*The authors found $82 \%$ for cyclosporine and $64 \%$ for tacrolimus.

** Only new cases of posttransplant hypertension.

MetS: metabolic syndrome; DM: diabetes mellitus; NODAT: New Onset Diabetes After Transplantation; HBP: high blood pressure.

studies by Gisbert et al. ${ }^{54}$ and Dehghani et al. ${ }^{56}$ revealed that hypertriglyceridemia is the most frequent dyslipidemia in posttransplanted patients.

There are several investigations about obesity before transplantation and its influence on transplantation, graft dysfunction and mortality. Nevertheless, there are few studies evaluating posttransplant obesity. Seo et al ${ }^{40}$ found $10 \%$ weight gain in patients after transplantation. The statistics found vary from $20 \%$ to $36 \%$ of obese individuals in the population investigated. ${ }^{38,46,65}$ Everhart et al., ${ }^{38}$ in a study assessing 774 patients, found the following risk factors for obesity: use of corticosteroids, genetic factors and recent marriage. Kouz et al. ${ }^{65}$ in turn, observed that obesity is more common in patients undergoing transplantation because of NASH compared to other etiologies. Regarding risk factors, obesity is associated with increased development of NODAT and de novo NASH. ${ }^{12}$

\section{Discussion}

The present review of the literature suggests that patients transplanted due to any etiology have a high incidence of NAFLD, mainly steatohepatitis (NASH), which is the phase with the greatest potential for progression of the disease in the posttransplant period. It occurs due to 
recurrence of the disease or the onset of de novo NASH in transplanted patients due to other diseases. The frequency of both increases according to the time of followup. Higher recurrence is found in the older series, which may be related to the type of immunosuppression used at the time, more strongly based on corticosteroids. ${ }^{9,30,39}$

In the more detailed evaluations, the association between de novo NASH and use of tacrolimus, ${ }^{12} \mathrm{DM},{ }^{12}$ dyslipidemia, ${ }^{12,30} \mathrm{HBP},{ }^{12}$ alcoholic cirrhosis, ${ }^{12}$ donor with a steatotic liver ${ }^{43}$ and weight gain after transplantation ${ }^{12,30,37}$ were observed. However, no differences were observed in the mean survival of transplant patients due to NASH compared to the survival of patients transplanted on the account of other etiologies even in the first year, when mortality associated with cardiovascular events is higher in patients transplanted due to NASH.

Similar to what is observed with NASH, there is a high prevalence of metabolic disorders in these patients, apparently related to the use of immunosuppressants.

When new cases of diabetes after transplantation (NODAT) are added to those of patients with diabetes prior to transplantation, prevalences of $50 \%$ can be found. ${ }^{10,19,21,31}$ NODAT was observed in $10 \%$ to $36 \%$ of the population and was related to obesity, positive family history, glucose intolerance prior to transplantation and hepatitis $\mathrm{C}$ as the etiology of transplantation, in addition to immunosuppressants, especially calcineurin inhibitors. ${ }^{53,62}$

Numerous studies have demonstrated a higher incidence of dyslipidemia and hypertension in posttransplant patients. Some of them compared patients using different immunosuppressants. Among calcineurin inhibitors, currently the basis of treatment, cyclosporine has been shown to be more associated with hypertension and dyslipidemia, while tacrolimus is associated with increased DM frequency as previously mentioned. ${ }^{45,55,58}$

Although poorly studied in posttransplant patients, obesity was more commonly found in transplanted individuals due to $\mathrm{NASH}^{65}$ compared to other etiologies, as well as association with NODAT and de novo NASH. ${ }^{12}$ MetS was found in approximately $50 \%$ of patients after transplantation with no difference being found between patients transplanted due to NASH or other etiologies. A possible explanation for this fact should be the interference of immunosuppressants in the factors (DM, HBP, dyslipidemia and obesity) associated with MetS. In patients with non-transplanted NASH there is a strong correlation between MetS and insulin resistance; however, few studies have evaluated insulin resistance in this population. The few studies ${ }^{14,45,59}$ evaluating insulin resistance based on the calculation of the HOMA index showed values very close to those considered normal. This aspect should be further evaluated in the future.

Our study has limitations, particularly its descriptive character, which does not allow conclusions based on strong scientific evidence. The heterogeneity of the studies regarding the topic addressed, the varied designs and the characteristics of the different populations hindered the performance of systematic analyses. Most of the studies evaluated were cross-sectional. Due to temporal differences related to the immunosuppressive regimen, many of these studies were not comparable, leading to biases in evaluation and clinical outcome.

\section{Conclusion}

Our review suggests that liver transplant patients have a high prevalence of steatosis and NASH, as well as posttransplant metabolic disorders. NAFLD/NASH after liver transplantation is usually not a serious disease and mortality is similar to that found in individuals who do not develop the disease.

Immunosuppressants appear to play an important role in the prevalence of NASH and its associated factors, as well as in the behavior of the disease. Further studies are still needed to better understand NAFLD/NASH after liver transplantation, especially its pathophysiology, treatment and prevention.

\section{Resumo}

Esteato-hepatite não alcoólica no pós-transplante de fígado: artigo de revisão

Introdução: A doença hepática gordurosa não alcoólica (DHGNA) é a terceira causa de transplante hepático no mundo. Tem elevada prevalência após transplante hepático (TH) e é representada pela recorrência da esteato-hepatite (NASH), ou por NASH de novo, que ocorre em pacientes transplantados por outra etiologia.

Objetivo: Realizar uma revisão da literatura para avaliar a relevância da recorrência ou do NASH de novo em pacientes transplantados de fígado.

Método: Realizada revisão da literatura através de artigos indexados no Medline, Scielo e Lilacs até 2016 publicados em inglês e português. Foram considerados elegíveis estudos que incluíram local e ano de publicação, prevalência e características clínicas dos pacientes.

Resultados: Foram identificados 110 artigos e selecionados 63, que avaliaram a recorrência de NASH, NASH de novo e sobrevida após o TH. A sobrevida foi de $90 \%$ a $100 \%$ em um ano e de $52-100 \%$ em 5 anos. A recorrência de 
esteatose variou de $15-100 \%$ e a de NASH de $4-71 \%$, enquanto esteatose e NASH de novo variaram de $18-67 \%$ e 3-17\%, respectivamente. A frequência de síndrome metabólica, diabetes, dislipidemia e hipertensão variaram de $45-58 \%, 18-59 \%, 25-66 \%$ e 52-82\%, respectivamente.

Conclusão: No pós-transplante de fígado, os pacientes apresentam elevada prevalência de recorrência, de NASH de novo e de distúrbios metabólicos. Entretanto, essas alterações parecem não influenciar a sobrevida dos pacientes.

Palavras-chave: Hepatopatia Gordurosa Não Alcoólica. Transplante de Fígado. Fígado Gorduroso. Síndrome Metabólica. Diabetes Mellitus.

\section{References}

1. Younossi ZM, Stepanova M. Changes in hepatitis A and B vaccination rates in adult patients with chronic liver diseases and diabetes in the U.S. population. Hepatology. 2011; 54(4):1167-78.

2. Powell EE, Cooksley WG, Hanson R, Searle J, Halliday JW, Powell LW. The natural history of nonalcoholic steatohepatitis: a follow-up study of fortytwo patients for up to 21 years. Hepatology. 1990; 11(1):74-80.

3. Bugianesi E, Leone N, Vanni E, Marchesini G, Brunello F, Carucci P, et al. Expanding the natural history of nonalcoholic steatohepatitis: from cryptogenic cirrhosis to hepatocellular carcinoma. Gastroenterology. 2002; 123(1):134-40.

4. Chalasani N, Younossi Z, Lavine JE, Diehl AM, Brunt EM, Cusi K, et al. The diagnosis and management of non-alcoholic fatty liver disease: practice Guideline by the American Association for the Study of Liver Diseases, American College of Gastroenterology, and the American Gastroenterological Association. Hepatology. 2012; 55(6):2005-23.

5. Ekstedt M, Hagström H, Nasr P, Fredrikson M, Stål P, Kechagias S, et al. Fibrosis stage is the strongest predictor for disease-specific mortality in NAFLD after up to 33 years of follow-up. Hepatology. 2015; 61(5):1547-54.

6. Charlton MR, Burns JM, Pedersen RA, Watt KD, Heimbach JK, Dierkhising RA. Frequency and outcomes of liver transplantation for nonalcoholic steatohepatitis in the United States. Gastroenterology. 2011; 141(4):1249-53.

7. Charlton MR. Improving long-term outcomes after liver transplantation. Clin Liver Dis. 2014; 18(3):717-30.

8. Vallin M, Guillaud O, Boillot O, Hervieu V, Scoazec JY, Dumortier J. Recurrent or de novo nonalcoholic fatty liver disease after liver transplantation: natural history based on liver biopsy analysis. Liver Transpl. 2014; 20(9):1064-71.

9. Contos MJ, Cales W, Sterling RK, Luketic VA, Shiffman ML, Mills AS, et al. Development of nonalcoholic fatty liver disease after orthotopic liver transplantation for cryptogenic cirrhosis. Liver Transpl. 2001; 7(4):363-73.

10. Ong J, Younossi ZM, Reddy V, Price LL, Gramlich T, Mayes J, et al. Cryptogenic cirrhosis and posttransplantation nonalcoholic fatty liver disease. Liver Transpl. 2001; 7(9):797-801.

11. Poordad F, Gish R, Wakil A, Garcia-Kennedy R, Martin P, Yao FY. De novo non-alcoholic fatty liver disease following orthotopic liver transplantation. Am J Transplant. 2003; 3(11):1413-7.

12. Dumortier J, Giostra E, Belbouab S, Morard I, Guillaud O, Spahr L, et al. Non-alcoholic fatty liver disease in liver transplant recipients: another story of "seed and soil". Am J Gastroenterol. 2010; 105(3):613-20.

13. Burke A, Lucey MR. Non-alcoholic fatty liver disease, non-alcoholic steatohepatitis and orthotopic liver transplantation. Am J Transplant. 2004; 4(5):686-93.

14. Anastácio LR, Oliveira MC, Diniz KG, Ferreira AM, Lima AS, Correia MI, et al. Adipokines, inflammatory mediators, and insulin-resistance parameters may not be good markers of metabolic syndrome after liver transplant. Nutrition. 2016; 32(9):921-7.

15. Marroni CA, Diehl JL, Leipnitz I, Pires LM, Brandão AB, Cassal AP, et al. Prevalence of high blood pressure in patients submitted to liver transplantation at the ISCMPA. Transplantation Proc. 1999; 31(7):3047.

16. Marroni CA, Hoppe L, Diehl JL, Leipnitz I, Brandão AB, Cassal AP, et al. Diabetes mellitus and liver transplantation in adults. Transplant Proc. 1999; 31(7):3046.
17. Parolin MB, Zaina FE, Araújo MV, Kupka E, Coelho JC. Prevalence of newonset diabetes mellitus in Brazilian liver transplant recipients: association with HCV infection. Transplant Proc. 2004; 36(9):2776-7.

18. Afzali A, Berry K, Ioannou GN. Excellent posttransplant survival for patients with nonalcoholic steatohepatitis in the United States. Liver Transpl. 2012; 18(1):29-37.

19. El Atrache MM, Abouljoud MS, Divine G, Yoshida A, Kim DY, Kazimi MM, et al. Recurrence of non-alcoholic steatohepatitis and cryptogenic cirrhosis following orthotopic liver transplantation in the context of the metabolic syndrome. Clin Transpl. 2012; 26(5):E505-12.

20. Dureja P, Mellinger J, Agni R, Chang F, Avey G, Lucey M, et al. NAFLD recurrence in liver transplant recipients. Transplantation. 2011; 91(6):684-9.

21. Agopian VG, Kaldas FM, Hong JC, Whittaker M, Holt C, Rana A, et al. Liver transplantation for nonalcoholic steatohepatitis: the new epidemic. Ann Surg. 2012; 256(4):624-33.

22. Kennedy C, Redden D, Gray S, Eckhoff D, Massoud O, McGuire B, et al. Equivalent survival following liver transplantation in patients with nonalcoholic steatohepatitis compared with patients with other liver diseases. HPB (Oxford). 2012; 14(9):625-34.

23. Barritt AS 4th, Dellon ES, Kozlowski T, Gerber DA, Hayashi PH. The influence of nonalcoholic fatty liver disease and its associated comorbidities on liver transplant outcomes. J Clin Gastroenterol. 2011; 45(4):372-8.

24. Yalamanchili K, Saadeh S, Klintmalm GB, Jennings LW, Davis GL. Nonalcoholic fatty liver disease after liver transplantation for cryptogenic cirrhosis or nonalcoholic fatty liver disease. Liver Transpl. 2010; 16(4):431-9.

25. Heuer M, Kaiser GM, Kahraman A, Banysch M, Saner FH, Mathé Z, et al. Liver transplantation in nonalcoholic steatohepatitis is associated with high mortality and post-transplant complications: a single-center experience. Digestion. 2012; 86(2):107-13.

26. Bhagat V, Mindikoglu AL, Nudo CG, Schiff ER, Tzakis A, Regev A. Outcomes of liver transplantation in patients with cirrhosis due to nonalcoholic steatohepatitis versus patients with cirrhosis due to alcoholic liver disease. Liver Transpl. 2009; 15(12):1814-20.

27. VanWagner LB, Bhave M, Te HS, Feinglass J, Alvarez L, Rinella ME. Patients transplanted for nonalcoholic steatohepatitis are at increased risk for postoperative cardiovascular events. Hepatology. 2012; 56(5):1741-50.

28. Houlihan DD, Armstrong MJ, Davidov Y, Hodson J, Nightingale P, Rowe IA, et al. Renal function in patients undergoing transplantation for nonalcoholic steatohepatitis cirrhosis: time to reconsider immunosuppression regimens? Liver Transpl. 2011; 17(11):1292-8.

29. Tanaka T, Sugawara Y, Tamura S, Kaneko J, Takazawa Y, Aoki T, et al. Living donor liver transplantation for non-alcoholic steatohepatitis: A single center experience. Hepatol Res. 2014; 44(10):E3-E10.

30. Singal AK, Guturu P, Hmoud B, Kuo YF, Salameh H, Wiesner RH. Evolving frequency and outcomes of liver transplantation based on etiology of liver disease. Transplantation. 2013; 95(5):755-60.

31. Malik SM, deVera ME, Fontes P, Shaikh O, Ahmad J. Outcome after liver transplantation for NASH cirrhosis. Am J Transplant. 2009; 9(4):782-93.

32. Hejlova I, Honsova E, Sticova E, Lanska V, Hucl T, Spicak J, et al. Prevalence and risk factors of steatosis after liver transplantation and patient outcomes. Liver Transpl. 2016; 22(5):644-55.

33. Neal DA, Tom BD, Luan J, Wareham NJ, Gimson AE, Delriviere LD, et al. Is there disparity between risk and incidence of cardiovascular disease after liver transplant? Transplantation. 2004; 77(1):93-9.

34. Johnston SD, Morris JK, Cramb R, Gunson BK, Neuberger J. Cardiovascular morbidity and mortality after orthotopic liver transplantation. Transplantation. 2002; 73(6):901-6.

35. Laish I, Braun M, Mor E, Sulkes J, HarifY, Ben Ari Z. Metabolic syndrome in liver transplant recipients: prevalence, risk factors, and association with cardiovascular events. Liver Transpl. 2011; 17(1):15-22.

36. Albeldawi M, Aggarwal A, Madhwal S, Cywinski J, Lopez R, Eghtesad B, et al. Cumulative risk of cardiovascular events after orthotopic liver transplantation. Liver Transpl. 2012; 18(3):370-5.

37. Lim LG, Cheng CL, Wee A, Lim SG, Lee YM, Sutedja DS, et al. Prevalence and clinical associations of posttransplant fatty liver disease. Liver Int 2007; 27(1):76-80.

38. Everhart JE, Lombardero M, Lake JR, Wiesner RH, Zetterman RK, Hoofnagle $\mathrm{JH}$. Weight change and obesity after liver transplantation: incidence and risk factors. Liver Transpl Surg. 1998; 4(4):285-96.

39. Charlton M, Kasparova P, Weston S, Lindor K, Maor-Kendler Y, Wiesner $\mathrm{RH}$. Frequency of nonalcoholic steatohepatitis as a cause of advanced liver disease. Liver Transpl. 2001; 7(7):608-14. 
40. Seo S, Maganti K, Khehra M, Ramsamooj R, Tsodikov A, Bowlus C, et al. De novo nonalcoholic fatty liver disease after liver transplantation. Liver Transpl. 2007; 13(6):844-7.

41. Sprinzl MF, Weinmann A, Lohse N, Tönissen H, Koch S, Schattenberg J, et al. Metabolic syndrome and its association with fatty liver disease after orthotopic liver transplantation. Transpl Int. 2013; 26(1):67-74.

42. Finkenstedt A, Auer C, Glodny B, Posch U, Steitzer H, Lanzer G, et al. Patatinlike phospholipasedomain-containing protein 3 rs738409-G in recipients of liver transplants is a risk factor for graft steatosis. Clin Gastroenterol Hepatol. 2013; 11(12):1667-72.

43. Kim CW, Chang Y, Sung E, Shin H, Ryu S. Serum ferritin levels predict incident non-alcoholic fatty liver disease in healthy Korean men. Metabolism. 2012; 61(8):1182-8.

44. Hanouneh IA, Macaron C, Lopez R, Feldstein AE, Yerian L, Eghtesad B, et al. Recurrence of disease following liver transplantation: nonalcoholic steatohepatitis vs hepatitis C virus infection. Int J Organ Transplant Med. 2011; 2(2):57-65.

45. Bianchi G, Marchesini G, Marzocchi R, Pinna AD, Zoli M. Metabolic syndrome in liver transplantation: relation to etiology and immunosuppression. Liver Transpl. 2008; 14(11):1648-54.

46. Laryea M, Watt KD, Molinari M, Walsh MJ, McAlister VC, Marotta PJ, et al. Metabolic syndrome in liver transplant recipients: prevalence and association with major vascular events. Liver Transpl. 2007; 13(8):1109-14.

47. Anastácio LR, Ferreira LG, Ribeiro HS, Liboredo JC, Lima AS, Correia MI Metabolic syndrome after liver transplantation: prevalence and predictive factors. Nutrition. 2011; 27(9):931-7.

48. Lv C, Zhang Y, Chen X, Huang X, Xue M, Sun Q, et al. New-onset diabetes after liver transplantation and its impact on complications and patient survival. J Diabetes. 2015;7(6):881-90.

49. Mirabella S, Brunati A, Ricchiuti A, Pierini A, Franchello A, Salizzoni M. Newonset diabetes after liver transplantation. Transplant Proc. 2005; 37(6):2636-7.

50. Ling Q, Xu X, Xie H, Wang K, Xiang P, Zhuang R, et al. New-onset diabetes after liver transplantation: a national report from China Liver Transplant Registry. Liver Int. 2016; 36(5):705-12.

51. Carey EJ, Aqel BA, Byrne TJ, Douglas DD, Rakela J, Vargas HE, et al. Pretransplant fasting glucose predicts new-onset diabetes after liver transplantation. J Transplant. 2012:614781.

52. Saliba F, Lakehal M, Pageaux GP, Roche B, Vanlemmens C, Duvoux C, et al. Risk factors for new-onset diabetes mellitus following liver transplantation and impact of hepatitis $\mathrm{C}$ infection: an observational multicenter study. Liver Transpl. 2007; 13(1):136-44.
53. Moon JI, Barbeito R, Faradji RN, Gaynor JJ, Tzakis AG. Negative impact of new-onset diabetes mellitus on patient and graft survival after liver transplantation: Long-term follow up. Transplantation. 2006; 82(12):1625-8.

54. Gisbert C, Prieto M, Berenguer M, Bretó M, Carrasco D, Juan M, et al. Hyperlipidemia in liver transplant recipients: prevalence and risk factors. Liver Transpl Surg. 1997; 3(4):416-22

55. Trotter JF, Wachs ME, Trouillot TE, Bak T, Kugelmas M, Kam I, et al Dyslipidemia during sirolimus therapy in liver transplant recipients occurs with concomitant cyclosporine but not tacrolimus. Liver Transpl. 2001; 7(5):401-8.

56. Dehghani SM, Taghavi SA, Eshraghian A, Gholami S, Imanieh MH, Bordbar MR, et al. Hyperlipidemia in Iranian liver transplant recipients: prevalence and risk factors. J Gastroenterol. 2007; 42(9):769-74.

57. Darstein F, König C, Hoppe-Lotichius M, Grimm D, Knapstein J, Zimmermann A, et al. New onset of diabetes after transplantation is associated with improved patient survival after liver transplantation due to confounding factor. Eur J Intern Med. 2015; 26(6):439-44.

58. Canzanello VJ, Textor SC, Taler SJ, Schwartz LL, Porayko MK, Wiesner RH, et al. Late hypertension after liver transplantation: a comparison of cyclosporine and tacrolimus (FK 506). Liver Transpl Surg. 1998; 4(4):328-34.

59. Veldt BJ, Poterucha JJ, Watt KD, Wiesner RH, Hay JE, Rosen CB, et al. Insulin resistance, serum adipokines and risk of fibrosis progression in patients transplanted for hepatitis C. Am J Transplant . 2009; 9(6):1406-13

60. Marchesini G, Bugianesi E, Forlani G, Cerrelli F, Lenzi M, Manini R et al. Nonalcoholic fatty liver, steatohepatitis, and the metabolic syndrome. Hepatology. 2003; 37(4):917-23.

61. Song JL, Gao W, Zhong Y, Yan LN, Yang JY, Wen TF, et al. Minimizing tacrolimus decreases the risk of new-onset diabetes mellitus after liver transplantation. World J Gastroenterol. 2016; 22(6):2133-41.

62. Øzbay LA, Møller N, Juhl C, Bjerre M, Carstens J, Rungby J, et al. Calcineurin inhibitors acutely improve insulin sensitivity without affecting insulin secretion in healthy human volunteers. Br J Clin Pharmacol. 2012; 73(4):536-45.

63. Abe $\mathrm{T}$, Onoe $\mathrm{T}$, Tahara $\mathrm{H}$, Tashiro $\mathrm{H}$, Ishiyama $\mathrm{K}$, Ide $\mathrm{K}$, et al. Risk factors for development of new-onset diabetes mellitus and progressive impairment of glucose metabolism after living-donor liver transplantation. Transplant Proc. 2014; 46(3):865-9.

64. Stepanova M, Rafiq N, Makhlouf H, Agrawal R, Kaur I, Younoszai Z, et al. Predictors of all-cause mortality and liver-related mortality in patients with non-alcoholic fatty liver disease (NAFLD). Dig Dis Sci. 2013; 58(10):3017-23.

65. Kouz J, Vincent C, Leong A, Dorais M, Räkel A. Weight gain after orthotopic liver transplantation: is nonalcoholic fatty liver disease cirrhosis a risk factor for greater weight gain? Liver Transpl. 2014; 20(10):1266-74. 